\title{
Design, optimization and validation of a flow cytometry assay for quantitation of Igg-anti-D (rho) in the industrial process control of the anti rho-gamma globulin production
}

\author{
Sergio A Oviedo ${ }^{1,2 *}$, Susana Vitali ${ }^{1}$, Jorge Zarzur ${ }^{1}$ \\ 1 Blood Products Laboratory National University of Cordoba, Argentina 2 Group Quality and Regulatory Affairs, School of \\ Chemistry, Catholic University of Cordoba, Argentina
}

\begin{abstract}
One of the main causes of the hemolytic disease of the newborn is due to the generation of anti-D antibodies, in response to a continuous antigenic challenge in pregnant mothers who do not possess the D antigen in their red blood cells. In order to prevent complications, the monitoring of anti-D antibody levels in pregnant women is carried out and the sensitization is prevented by prophylaxis with anti-D immunoglobulin (IgG anti-D). To date, the monitoring and titration of anti-D in plasma and finished products (IgG anti-D) is carried out continuous flow analysis with a Technicon Autoanalyzer, Radio Immuno Assay (RIA) and Enzymo Immuno Assay (EIA). In our laboratory, for the quantification of anti-D antibodies of the Gamma-Rho UNC and the products of the elaboration process, a "house made" technique of flow cytometry was developed as an alternative test to the reference method of the European Pharmacopoeia. Polyclonal anti-Rho antibodies and an anti FITC (fluorescein isothiocyanate) -labeled human IgG were used to measure the concentration of anti-D antibodies in a commercial preparation of gammaglobulin, semi-processed and human plasma. The method was developed using the $1^{\text {st }}$ international WHO standard for anti-D IgG (69/419). At the concentration of red cells used in the method $(5 \times 104$ cells/ul) there is no interference by auto agglutination. The obtained dose response curve (MFI vs. Log C) was linear in the adopted work range, presenting a correlation coefficient of 0.99 . The specificity and recovery tests were satisfactory, the negative controls showed insignificant levels of fluorescence and did not present a serious interference in the determination. Knowing that the levels of anti-D sites antigen by red blood cell, vary according to the phenotype, our results show that the globules with phenotypes R1R1 present the best performance for this test, and can be replaced if necessary by R1R 2 cells.

The method was validated following the criteria of the group of Experts $\mathrm{N}^{\circ} 6 \mathrm{~B}$ of the NIBSC and the European Pharmacopoeia who have standardized a similar procedure to be applied in the assessment of anti-D. Flow Cytometry allowed to obtain accurate, precise, sensitive and specific determinations at different concentrations of anti-D (100-0.9 ug/ ml) and in different biological matrices such as finished product, pre-filled concentrate product and fraction II of Cohn's method. The advantages found in the application of this method, in addition to the relatively low cost, include a strong fluorescence signal that does not require amplification, the use of highly diluted samples that minimize the risk of agglutination by IgM-Anti D or polymers. It is a simple, fast and reliable method to determine the serum levels of anti-D or quantify the concentration in an immunoglobulin solution.
\end{abstract}

Citation: Oviedo SA, Vitali S, Zarzur J (2018) Desing, Optimization and Validation of a Flow Cytometry Assay for Quantitation of Igg-Anti-D (Rho) in the Industrial Process Control of the Anti Rho-Gammaglobulin Production, GJBAHS 7: 4.

Received: September 07, 2018; Accepted: September 18, 2018; Published: September 25, 2018

Copyright: (C2018 Oviedo SA, et al. This is an open-access article distributed under the terms of the Creative Commons Attribution License, which permits unrestricted use, distribution, and reproduction in any medium, provided the original author and source are credited.

Competing interests: The authors have declared that no competing interests exist.

Sources of funding: No funding.

*Email: soviedo@hemo.unc.edu.ar,0732148@ucc.edu.ar 


\section{Keywords:}

Blood products, Cytometry assay, IgG-anti-D (Rho), Process control, Industrial process, Validation

\section{Introduction}

One of the major causes of haemolytic disease in newborns is immunization with $\operatorname{Anti-Rh}(+)$ Antibodies in D-incompatible pregnancies. To prevent complications, pregnant women are monitored by determining the level of anti-D antibodies present and avoiding sensitization by prophylaxis with anti-D immunoglobulin (IgG Anti-D) produced from human plasma. The content of anti-D antibodies in this medicine are determined by the manufacturer and the regulatory health authority, being determined in each batch of the finished product before its release to the market. Initially it was used for the monitoring and evaluation of anti-D in plasma of pregnant and finished products (IgG Anti-D) the anti-globulin test or Coombs test [1] or by the continuous flow analysis of haemagglutination with a Technicon Autoanalyzer [2-7]. The automatic haemagglutination method has been considered as a reference by the European Pharmacopoeia (EP); despite this, some groups of experts and regulatory bodies have replaced such methodology by radio immuno assay (RIA) [8-10], flow cytometry and a competitive enzyme immunoassay (EIA). From an international collaborative study, these alternatives to the reference method of the current European Pharmacopoeia have been successfully investigated [10-18].

While the competitive EIA and Flow Cytometry that is referenced in this study has been described in detail above, its use in the quantification of anti D in plasma and finished product [16-20], the flow cytometry method that is now described advances in its application during industrial processes to obtain the anti D gamma globulin product.

The described flow cytometry method focuses on the validation carried out to meet the criteria established for the establishment of a quality assurance system and the regulatory requirements of good manufacturing practices in the process of obtaining anti D gamma globulin starting from hyperimmune plasma and fraction II obtained by Chon Oncley until the finished product
[12-14,21-23]. The technique is based on the binding of immunoglobulin to D-positive cells, with the subsequent use of an anti-human immunoglobulin $\mathrm{G}$ ( $\mathrm{IgG}$ ) fragment labelled with secondary fluorescence and read by flow cytometry. Each sample where anti-D immunoglobulin is quantified is analysed in comparison with the international reference preparation, calibrated in international units (IU), which allows to give a specification in $\mathrm{IU} / \mathrm{ml}[20,24]$. In relation to flow cytometry, Expert Group No 6B of the NIBSC standardized a procedure to be applied in the evaluation of anti-D in anti-D IgG solutions [24]. In our laboratory, for the quantitation of anti-D antibodies of the Gamma-Rho UNC a Flow Cytometry technique was developed, designed according to procedures described in the literature $[20,24]$ and validated according to the indicated by the NIBSC expert group [18,24]. The development and optimization of a method of flow cytometry is reported using anti-Rho polyclonal anti human IgG and FITC (fluorescein isothiocyanate)-labeled for measuring the concentration of anti-D antibodies. The technique is based on binding of immunoglobulin to D-positive cells, with subsequent use of a secondary fluorescencelabelled anti-human immunoglobulin G ( $\mathrm{IgG})$ fragment and read-out by flow cytometry.

\section{Materials and Methods}

\section{Brief description of the flow cytometry test}

Flow cytometry involves the measurement of physical or chemical characteristics of cells when they cross in a continuous flow through the passage of the cytometer. The laser is in the detection cell and hits the cells when they pass through the cell one at a time. From this interaction a luminescence is emitted resulting from the excitation of the fluorescein adsorbed on the surface of the cells. The light is detected by the Forward Scatter (FS) (determines the diffraction of the light). The detector FS converts the light into a voltage pulse proportional to the size of the particle. Our Cytometry method measures the size of the erythrocyte light reflection (FS) and fluorescence intensity emitted by the anti-IgG/FITC conjugate specifically bound to the anti-D IgG attached to the surface of the red globule, being is proportional to the concentration of Anti-D present. 


\section{Preparation of cell suspension}

A $0.2 \%$ cell suspension $(5 \times 104$ cells / $\mu$ in Phosphate Buffer Saline-PBS $\mathrm{pH}$ 7.2) of $\mathrm{RhO}$ R1R1 red blood cells (R1R2 can be used) and red cells Rh-rr as a control, preserved between 24 hours and two weeks at $4^{\circ} \mathrm{C}$, was used.

\section{Problem samples}

Plasma samples were diluted 1/5, 1/10, 1/20, 1/50 and $1 / 100$ with $1 \%$ PBS-BSA (Phosphate BufferBovine Serum Albumin pH 7.2). The Fraction II and the finished product were diluted $1 / 200,1 / 500$ and $1 / 1000$ with the same buffer.

\section{Sensitization, immunoglobulin binding to the cell surface}

Fifty microliters of red cell suspension $(0 \%, 2 \%)$ was incubated with $50 \mu \mathrm{l}$ diluted in PBS/ 1\% BSA; anti-D standard (IRP 68/419 OMS- NIBSC), human plasma, intermediate fractions of the Cohn process, (Fraction II), pre-filled IgG concentrate or finished product gamma globulin, at $4^{\circ} \mathrm{C}$ for $30 \mathrm{~min}$ with agitation at 5-min intervals. After washing three times with $\mathrm{PBS}-1 \% \mathrm{BSA}$, the red cells were incubated with $50 \mu \mathrm{l}$ of the 1/50 dilution of a goat Fab anti-human IgG FITC, the most suitable conjugate dilutions were $1 / 50$ and 1/100 (Figure 1). Finally, the labeled cells were resuspended in $1 \mathrm{ml}$ of PBS-1\% BSA and analysed by flow cytometry (Epics XL-MCL Cytometer-Coulter, corp., Luston, $\mathrm{UK})$.

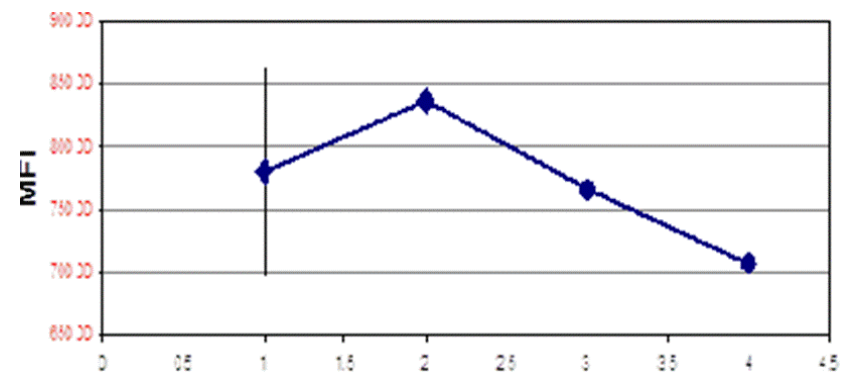

Figure 1: Calibration curve of the conjugate dilution.

\section{Standard curve}

To establish the standard curve prepared dilutions of $1^{\text {st }}$ International Reference for human anti-D immunoglobulin preparation IRP 68/419 OMS provided by the NIBSC in a concentration range of $1500 \mathrm{ng} / \mathrm{ml}$ (7.5 IU/ml)-180 (0.9 IU/ml) ng/ml.
The corresponding values of MFI (Mean Fluorescence Intensity) were between 600 and 1900. To set the minimum level of detection of each curve, not anti-D sensitized cells were incubated in buffer ran and PBS-BSA 1\%. MFI values obtained in 800 averaged. Five similar curves were run together and the value of the average curve was determined; 2 SD (standard deviation) values of each point of the standard curves and these calculated values of the upper and lower limits of each reading was calculated.

\section{Flow cytometry}

Epics XL-MCL Cytometer (Coulter, corp., Luston, UK) was checked and calibrated using standard Immunocheck particles (Becton Dickinson, Oxford, UK). The red blood cell samples automatically pass through the cytometer according to their FS (forward scatter) and SS (side scatter). To work, a limit of 25,000 events is determined at a flow rate of 600 cells per second with a power of $1300 \mathrm{~V}$. A reference curve was constructed and two positive controls were prepared with red cells or Rho $(+)$ R1R1 sensitized with Anti-D, three negative controls with GR 0Rho (+) R1R1 without sensitization and three negative controls with GR ORho (-) rr sensitized with anti-D. A histogram was generated using the fluorescence parameter (FL1) and the FS and SS parameters of the cells. The mean fluorescence intensity of the samples is plotted according to the logarithm of the anti-D concentration.

\section{Statistical treatment}

The statistical treatment of the data is done using nonparametric statistics and processed with Microsoft's Excel 7.0 program and Method Validator 1.15 made by Phillip Marquis 1999 and cytometer output data with the Win MID 2.0 program made by Joseph Trotter (Freeware).

\section{Results}

\section{Calibration of the cytometer}

Epics XL-MCL Cytometer (Coulter, corp., Luston, UK) was checked and calibrated using standard Immunocheck particles (Becton Dickinson, Oxford, UK). The red cells samples automatically pass through the cytometer according to their FS (forward scatter) and SS (side scatter). After 
defining the working conditions and the protocol, to be used with the cytometer, it was determined that the most suitable conjugate dilutions were $1 / 50$ and $1 / 100$ (Figure 1). It was determined to work with 25,000 events at a flow rate of 600 events/sec (Figure 2).

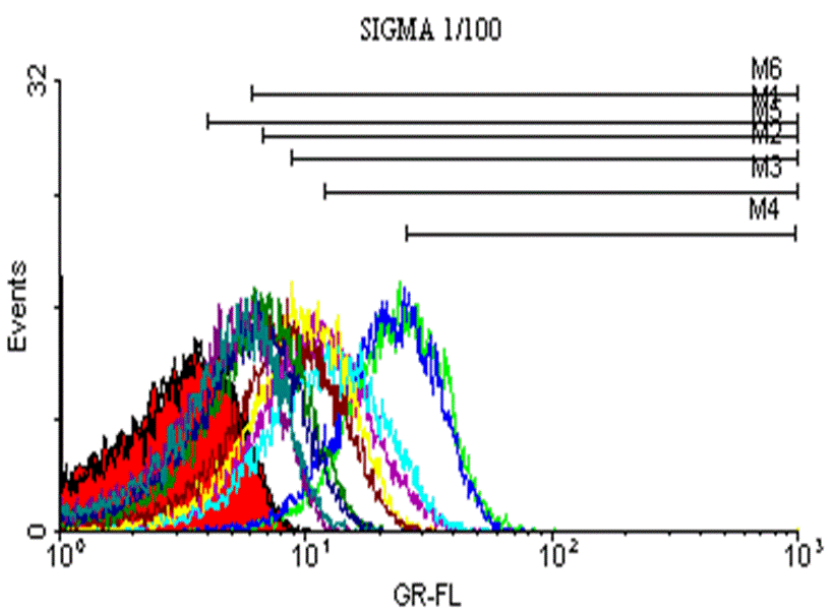

Figure 2: Work and flow rate events.

Regarding the negative controls that are observed in all cases (R1R1 or rr cells, facing anti-D IgG, antiD IgG negative controls and all probable dilutions of conjugate), the intensity signal corresponds to a negative, not nonspecific unions or other phenomenon that causes false positives was observed (Figure 3).
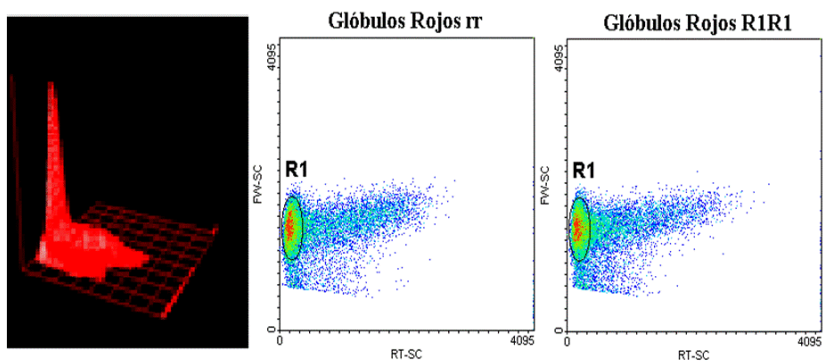

Figure 3: Forward (FS) and side (SS) scatter graphs of a homogeneous population of non-sensitized cells.

In order to determine the most suitable conjugate for our experience, 26 tubes are processed in duplicate, 13 for R1R1 and 13 for rr, red cells. A $1 / 100$ dilution of the conjugate is performed, using two conjugates of different commercial brands (Sigma Anti Human IgG -Fc specific FITC Conjugate-F9512 and Kallestad FITC Conjugate \#30446). 10 tubes are used to control with serial double dilutions (960 ng/ml-60 ng/ml) of a commercial gamma globulin of $250 \mu \mathrm{g} / \mathrm{ml}$. One tube will be used as cellular control and as control of each conjugate. In all cases two batteries are prepared one for each conjugate. The Figure 4 shows that the SIGMA conjugate presents a greater signal of fluorescence in the peaks, resulting in the most suitable for our test. A good correlation was obtained between the fluorescence intensity expressed as the mean equivalent of soluble fluorescein adsorbed to the standard particles (MESF) and the fluorescence signal emitted by the cytometer. Ten experiments where a mixture of particles with different fluorescence levels was used. The linear relationship between the mean of MFI emitted by the apparatus and the MESF is shown in Figure 5. The peak's SD values were in a range of 1.4 to 7.6 for the points with higher and lower intensity respectively.

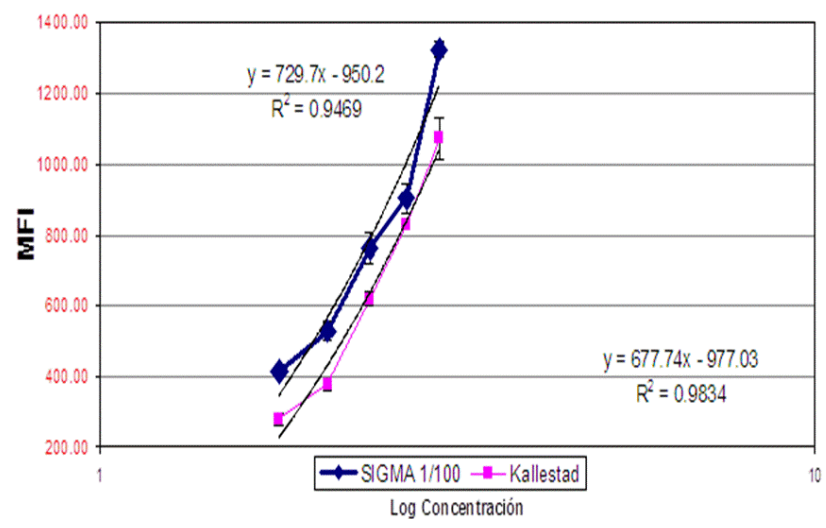

Figure 4: Comparative curve of the conjugates.

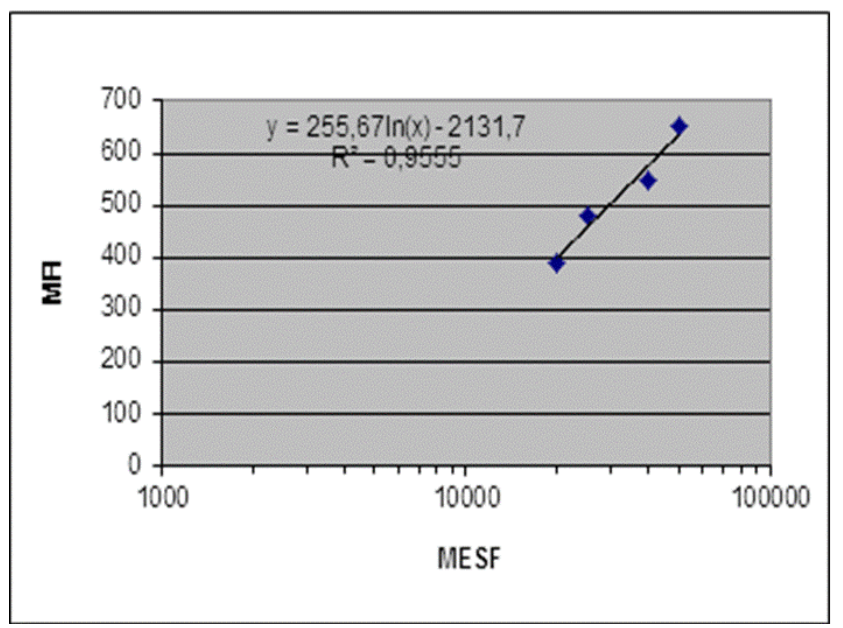

Figure 5: Calibration curve of the flow cytometer, correlation between MFI $v s$ MESF.

The histograms of the fluorescence parameters that were plotted according to the anti-Rho IgG concentrations can be seen in Figure 6. The working area was determined with the forward (FS) 
and lateral (SS) dispersion of a homogenous population of non-sensitized cells (Figure 7a) and as seen in Figure $7 \mathrm{~b}$ at a high concentration of antiRho, the globules sensitized reds tend to autoaggregate; no significant agglutination was observed for anti-Rho IgG concentrations less than or equal to $960 \mathrm{ng} / \mathrm{ml}(4.8 \mathrm{IU} / \mathrm{ml})$, when increasing it an increase in FS was observed, so work was carried out in concentration ranges $960 \leq$ $\mathrm{ng} / \mathrm{ml}$.

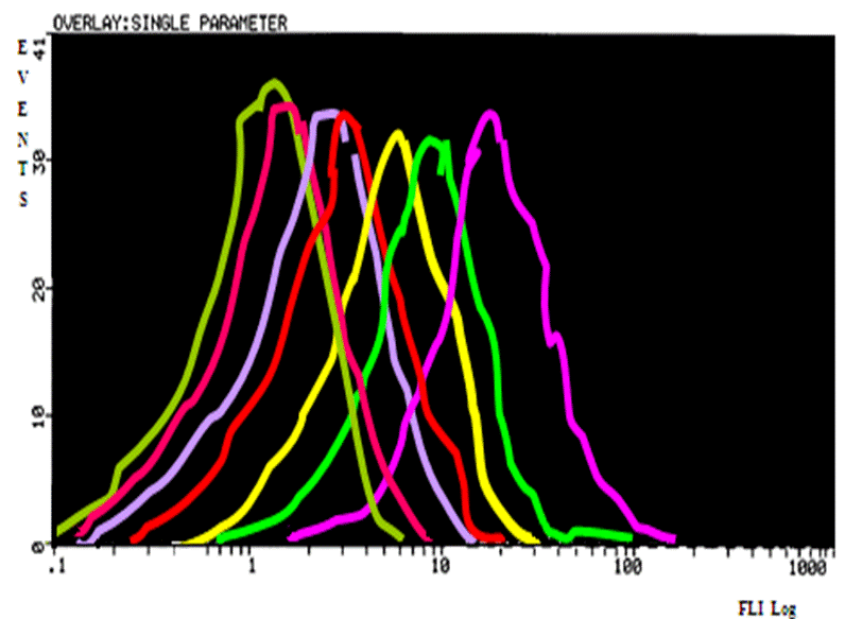

Figure 6: FL1 Histogram of Fluorescence Stockings obtained from 7 dilutions of the WHO 68/419 standard using GR Rho + R1R1, (pink) $960 \mathrm{ng} / \mathrm{ml} \mathrm{AD,} \mathrm{(Dark} \mathrm{green)} 480 \mathrm{ng} / \mathrm{ml} \mathrm{AD,} 240$ $\mathrm{ng} / \mathrm{ml} \mathrm{AD,} \mathrm{(Red)} 120 \mathrm{ng} / \mathrm{ml} \mathrm{AD,} \mathrm{(Light} \mathrm{Green)} 60 \mathrm{ng} / \mathrm{ml} \mathrm{AD}$, (Purple) $15 \mathrm{ng} / \mathrm{ml} \mathrm{AD}$.

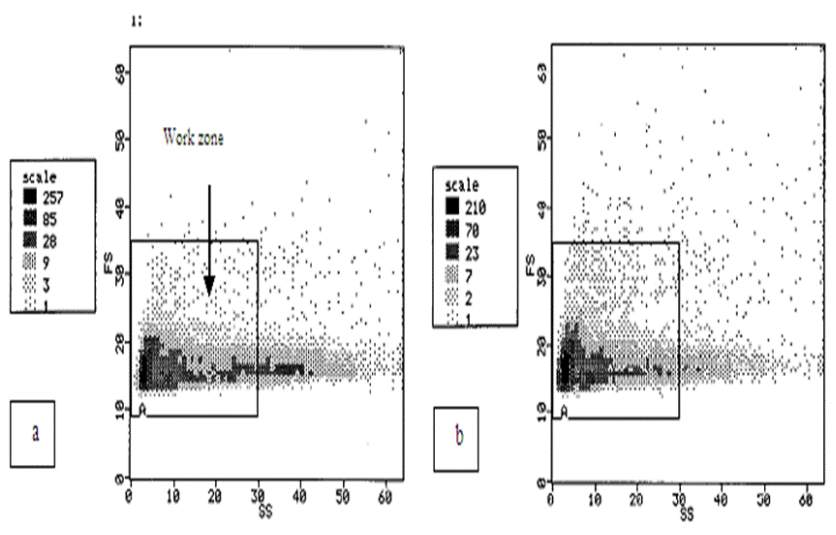

Figure 7: a) Working region selected for Rho + R1R1 red blood cells according to the FS and SS of washed cells not sensitized in a concentration of $0.2 \%$ in PBS. b) Increase of FS of GR R1R1 sensitized with Anti-Rho IgG Standard 68/419 $960 \mathrm{ng} / \mathrm{ml}$.

\section{Effect of the red blood cell phenotype}

Different phenotypes of suspensions of red blood cells at 2\% PBS were tested to optimize the assay (phenotype: R1R1, R1R2, R1r' and R1r). Table 1 show the estimated concentrations in the individual trials, means, standard deviations and $\mathrm{CV} \%$, for each phenotype. These values suggest that the tests are repeatable for each sample and each phenotype.

As seen in Figure 8, the R1R1 phenotype presented a greater fluorescence signal and, therefore, a greater amount of anti-D was adsorbed than in the rest of the phenotypes. Similar result's present cells of phenotype R1R2, this is verified in the comparison of concentrations shown in Table 1.

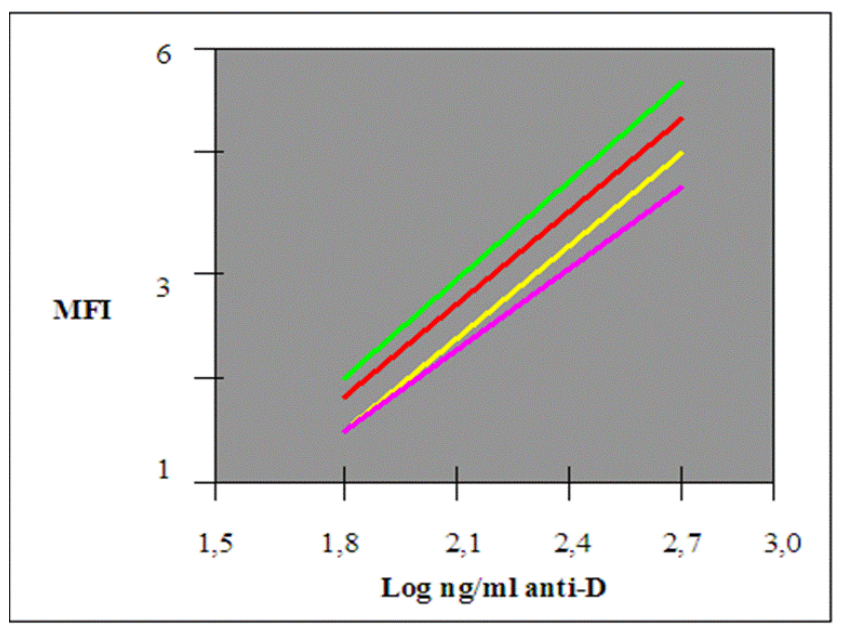

Figure 8: Standard curves using red blood cells of phenotype: R1R1 (Green), R1R2 (Red), R1r' (Yellow), R1r (Pink).

\section{Standard curve and cutt off}

To establish the standard curve, dilutions of WHO reference preparation were used in a concentration range of $30-480 \mathrm{ng} / \mathrm{ml}$. The corresponding values of MFI were between 1.4 and 4.5. To establish the minimum level of detection, non-sensitized cells were run, with MFI values averaged 1.2 (Figure 9).

A linear and proportional to the log of the anti-D concentration fluorescence response was obtained in the measured range. The linear regression of 270 points was $r=0.963$. The linear measurement range was set between 120-240 ng/ ml and was the most acceptable for our purpose.

Seven similar curves were run with each other (Figure 10a) and the average curve and two SD values were calculated at each point and the upper and lower limits of each reading were calculated and plotted. To determine the appropriate limits for our purpose, 19 standard curves were tested. As shown in Figure 10, at high concentrations of anti D there are no significant deviations, in the diluted samples three showed deviations from the upper 
limit $(0.24 \mu \mathrm{g} / \mathrm{ml})$ and one below the lower limit $(120 \mathrm{ng} / \mathrm{ml})$. The limits of $120-240 \mathrm{ng} / \mathrm{ml}$ were taken as validation criteria of the standard curve.

The interpretation pattern was established by comparing the results obtained with 135 serum samples (55 positive and 80 negative) tested by flow cytometry. A dilution 1:1024 of Anti-D standard (NIBS) determined by flow cytometry, corresponded with an anti-D level of $10 \mathrm{ng} / \mathrm{ml}(0.05$ $\mathrm{IU} / \mathrm{ml}$ ). Considering that the minimal requirements of anti-D concentration in plasma directed to the production of Anti-D gammaglobulin is 12.68 $\mathrm{ng} / \mathrm{ml}(0.063 \mathrm{IU} / \mathrm{ml})$, flow cytometry was adjusted to give the positive/negative cut off point at 10 $\mathrm{ng} / \mathrm{ml}(0.05 \mathrm{IU} / \mathrm{ml})$.

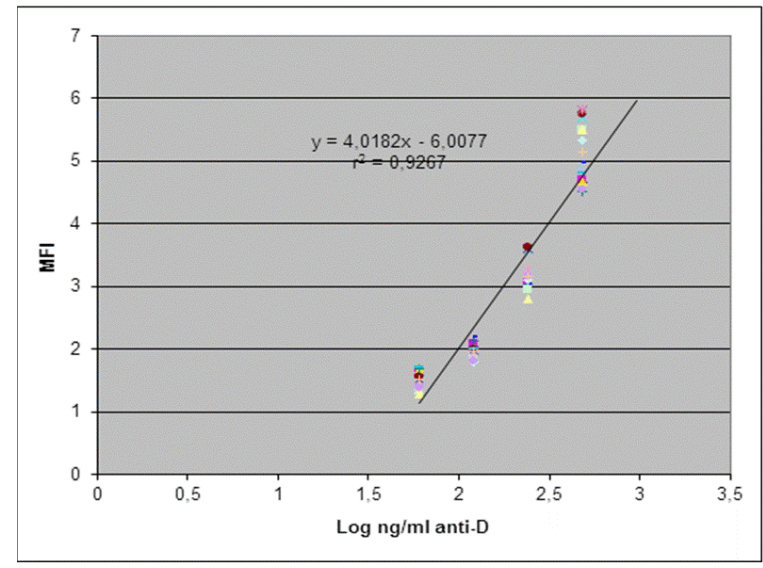

Figure 9: Construction of the standard curve. A total of 18 curves were run and its linear regression was $\mathrm{r}=0.963$.

\section{Reproducibility and repeatability}

To assess the reproducibility and repeatability of the flow cytometry, the assay was carried out on the diluted samples of the reference standard $(480,120$ and $30 \mathrm{ng} / \mathrm{ml}$ ), anti-D plasma, Cohn's Fraction II and commercial gammaglobulins in ten times simultaneously (intra-assay), and at different days (inter-assay); the $\% \mathrm{CV}$ was $4.95 \%$ for high concentration, $3.36 \%$ for intermediate concentration and $4.78 \%$ for low concentration. In the results, two sources of intra-assay variation were detected, linked to variations in the cytometer and the samples preparation and dilution (Table 2). Tables $3 \mathrm{a}$ and $3 \mathrm{~b}$ reveals a good repeatability inter-assay, indicated by the coefficient of variation on representatives samples according to Thorpe and Schäffner in the collaborative study of the European Union and suggests that the test presents repeatability for each point.
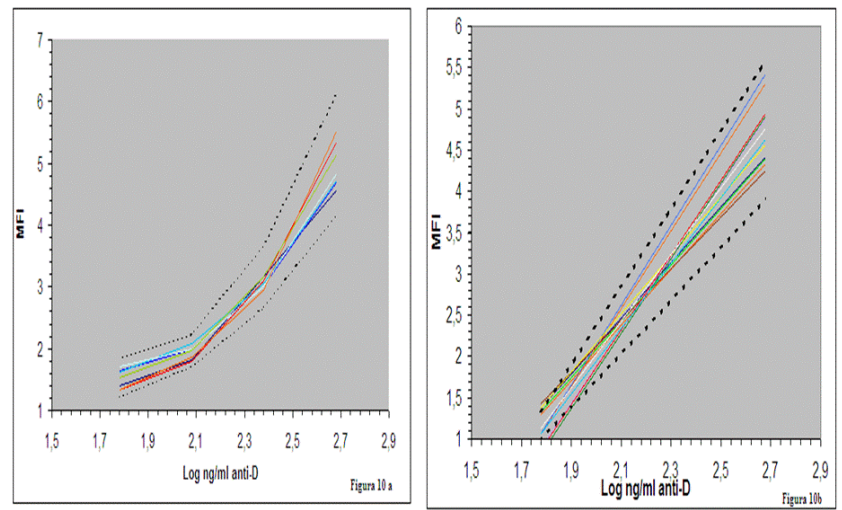

Figure 10: (a) Determination of the lower and upper limits (-----) and the values of 2DS for the mean standard curve. The limit lines were used for the approval of the standard curves. (b) From 19 standard curves 15 were found completely within the lower and upper limit lines.

Table 1: Red blood cells phenotype effect.

\begin{tabular}{lllllll}
\hline Phenotype & \multicolumn{1}{c}{ R1R1 } & \multicolumn{5}{c}{ R1R2 } \\
\hline ng STD & 480 & 120 & 60 & 480 & 120 & 60 \\
\hline & 480.45 & 119.70 & 60.30 & 478.75 & 118.00 & 60.10 \\
\cline { 2 - 6 } ng Rec. & 475.80 & 118.98 & 60.00 & 477.30 & 119.00 & 56.90 \\
\cline { 2 - 6 } & 481.06 & 120.00 & 59.45 & 476.89 & 118.5 & 59.89 \\
\hline Media & 480.03 & 121.00 & 60.10 & 477.00 & 116.78 & 60.05 \\
\hline
\end{tabular}




\begin{tabular}{|c|c|c|c|c|c|c|}
\hline SD & 2.39 & 0.84 & 0.36 & 0.86 & 0.95 & 1.56 \\
\hline $\mathrm{VC} \%$ & 0.5 & 0.7 & 0.6 & 0.2 & 0.8 & 2.6 \\
\hline $\mathrm{SD}+2$ & 484.12 & 121.59 & 60.69 & 479.21 & 119.97 & 62.35 \\
\hline SD-2 & 474.54 & 118.24 & 59.23 & 475.76 & 116.17 & 56.12 \\
\hline Phenotype & $\mathrm{R} 1 \mathrm{r}^{\prime}$ & & & $\mathrm{R} 1 \mathrm{r}$ & & \\
\hline ng STD & 480 & 120 & 60 & 480 & 120 & 60 \\
\hline \multirow{4}{*}{ ng Rec. } & 476.35 & 117.45 & 60.10 & 465.98 & 120.21 & 60.10 \\
\hline & 469.40 & 117.67 & 56.90 & 475.35 & 114.78 & 56.90 \\
\hline & 474.45 & 118.25 & 57.98 & 474.95 & 118.25 & 57.98 \\
\hline & 475.60 & 117.33 & 58.87 & 477.60 & 117.33 & 56.89 \\
\hline Media & 473.95 & 117.675 & 58.46 & 473.47 & 117.64 & 57.96 \\
\hline SD & 3.13 & 0.40 & 1.35 & 5.12 & 2.254 & 1.51 \\
\hline $\mathrm{VC} \%$ & 0.7 & 0.3 & 2.3 & 1.08 & 1.9 & 2.6 \\
\hline $\mathrm{SD}+2$ & 480.21 & 118.49 & 61.17 & 483.72 & 122.15 & 60.98 \\
\hline SD-2 & 467.68 & 116.85 & 55.74 & 463.21 & 113.13 & 54.94 \\
\hline
\end{tabular}

Table 2: Accuracy and reproducibility of the standard (a) and control samples (b).

\begin{tabular}{llll}
$\begin{array}{l}\text { Intraass } \\
\text { ay }\end{array}$ & (a) Reference Standard 68/419 $\mathbf{W H O}$ in $\mathbf{n g} / \mathbf{m l}$ \\
\hline $\begin{array}{l}\text { Concentr } \\
\text { ation }\end{array}$ & 480 & 120 & 30 \\
\hline $\mathrm{n}$ & 10 & 10 & 10 \\
\hline $\begin{array}{l}\text { Average } \\
\text { MFI }\end{array}$ & 4.79 & 1.98 & 1.25 \\
\hline SD & 0.24 & 0.07 & 0.06 \\
\hline VC \% & 4.95 & 3.36 & 4.78 \\
\hline $\begin{array}{l}\text { Intraass } \\
\text { ay }\end{array}$ & \begin{tabular}{l} 
(b) Samples Control $\mathbf{\mu g} / \mathbf{m l}$ \\
\hline Sample
\end{tabular} & $\begin{array}{l}\text { Pool } \\
\text { Plasma }\end{array}$ & of Cohn \\
\hline
\end{tabular}

Table 3a: Accuracy and repeatability of standard.

\begin{tabular}{lllll}
\hline $\begin{array}{l}\text { Concentr } \\
\text { ation }\end{array}$ & 12.5 & 30.2 & 197.2 & 179.5 \\
\hline $\mathrm{n}$ & 10 & 10 & 10 & 10 \\
\hline $\begin{array}{l}\text { Average } \\
\text { MFI }\end{array}$ & 2.08 & 11.26 & 3.12 & 3.49 \\
\hline $\mathrm{SD}$ & 0.06 & 0.05 & 0.16 & 0.17 \\
\hline $\mathrm{VC} \%$ & 3.06 & 4.32 & 5.16 & 4.93 \\
\hline $\begin{array}{l}\text { \% } \\
\text { Recovery }\end{array}$ & 113.6 & 91.56 & 98.33 & 109.46 \\
\hline
\end{tabular}

${ }^{*}$ Commercial gamma globulins: Concentration $1=204 \mu \mathrm{g} / \mathrm{ml}$, $2=164 \mu \mathrm{g} / \mathrm{ml}$

Pool $=11 \mu \mathrm{g} / \mathrm{ml}$, Cohn's Fraction II $=33 \mu \mathrm{g} / \mathrm{ml}$.

\section{Interassay: Reference Standard 68/419 WHO in ng/ ml}




\begin{tabular}{|c|c|c|c|c|c|c|c|c|c|c|c|}
\hline \multirow[t]{2}{*}{$\mathrm{ng} / \mathrm{ml}$} & \multicolumn{7}{|l|}{ MFI } & \multirow[t]{2}{*}{ SD } & \multirow[t]{2}{*}{$\mathrm{VC} \%$} & \multirow[t]{2}{*}{$+2 \mathrm{SD}$} & \multirow[t]{2}{*}{$-2 S D$} \\
\hline & M1 & M2 & M3 & M4 & M5 & 6 & $\begin{array}{l}- \\
\mathbf{X}\end{array}$ & & & & \\
\hline 480 & 5.95 & 5.12 & 5.06 & 5.44 & 4.76 & 5.22 & 5.26 & 0.40 & 7.69 & 8.38 & 4.45 \\
\hline 240 & 3.11 & 3.17 & 3.21 & 2.95 & 3.01 & 3.34 & 3.13 & 0.14 & 4.49 & 5.57 & 2.85 \\
\hline 120 & 1.8 & 1.97 & 1.88 & 1.84 & 2.11 & 2.01 & 1.93 & 0.12 & 6.01 & 3.97 & 1.70 \\
\hline 60 & 1.31 & 1.53 & 1.39 & 1.31 & 1.63 & 1.59 & 1.46 & 0.14 & 9.71 & 1.46 & 1.18 \\
\hline 30 & 1.11 & 1.23 & 1.27 & 1.22 & 1.3 & 1.2 & 1.22 & 0.06 & 5.36 & 1.22 & 1.09 \\
\hline
\end{tabular}

*Declared concentration for H: $150 \mu \mathrm{g} /$ vial, P: $220 \mu \mathrm{g} / \mathrm{vial}, \mathrm{B}: 164 \mu \mathrm{g} / \mathrm{vial}$

Table 3b: Control samples.

Interassay: Control Samples

\begin{tabular}{|c|c|c|c|c|c|c|c|c|c|}
\hline \multirow{2}{*}{$\begin{array}{l}\text { Product } \\
\text { Dilución }\end{array}$} & \multicolumn{3}{|c|}{ Gamma $H^{*}$} & \multicolumn{3}{|c|}{ Gamma $P^{*}$} & \multicolumn{3}{|c|}{ Gamma B* } \\
\hline & $1 / 250$ & $1 / 500$ & $1 / 750$ & $1 / 350$ & $1 / 700$ & $1 / 1000$ & $1 / 250$ & $1 / 500$ & $1 / 1000$ \\
\hline \multirow[t]{6}{*}{ MFI } & 1.21 & 1.16 & 1.05 & 1.37 & 1.24 & 1.06 & 1.21 & 1.15 & 1.02 \\
\hline & 1.18 & 1.16 & 1.04 & 1.39 & 1.24 & 1.06 & 1.23 & 1.15 & 1.03 \\
\hline & 1.19 & 1.17 & 1.04 & 1.39 & 1.25 & 1.06 & 1.19 & 1.13 & 0.98 \\
\hline & 1.22 & 1.19 & 1.04 & 1.38 & 1.23 & 1.07 & 1.22 & 1.14 & 1.00 \\
\hline & 1.20 & 1.14 & 1.06 & 1.3 & 1.15 & 1.05 & 1.21 & 1.16 & 1.01 \\
\hline & 1.18 & 1.15 & 1.05 & 1.27 & 1.22 & 1.04 & 1.23 & 1.13 & 1.02 \\
\hline Average MFI & 1.19 & 1.161 & 1.05 & 1.35 & 1.22 & 1.06 & 1.215 & 1.14 & 1.01 \\
\hline SD & 0.016 & 0.017 & 0.008 & 0.05 & 0.04 & 0.01 & 0.015 & 0.012 & 0.018 \\
\hline $\mathrm{VC} \%$ & 1.36 & 1.48 & 0.78 & 3.83 & 2.99 & 0.98 & 1.25 & 1.06 & 1.77 \\
\hline $\mathrm{ug} / \mathrm{ml}$ & 149.50 & 150.25 & 142.64 & 236.25 & 220.86 & 192.00 & 151.87 & 147.41 & 183.64 \\
\hline$\%$ Recovery & 99.66 & 100.16 & 95.09 & 107.39 & 100.39 & 87.27 & 92.61 & 89.89 & 111.97 \\
\hline$+2 \mathrm{SD}$ & 1.23 & 1.20 & 1.06 & 1.45 & 1.29 & 1.08 & 1.24 & 1.17 & 1.04 \\
\hline$-2 \mathrm{SD}$ & 1.16 & 1.13 & 1.03 & 1.25 & 1.15 & 1.04 & 1.18 & 1.12 & 0.97 \\
\hline
\end{tabular}

${ }^{*}$ Declared concentration for H: $150 \mu \mathrm{g}$ / vial, P: $220 \mu \mathrm{g}$ / vial, B: $164 \mu \mathrm{g}$ / vial

\section{Recovery of anti-D}

The estimated concentration of anti-D for each measured point in three commercial products presented a $\% \mathrm{cv}$ in the range of $1 \%$ to $7.5 \%$, (Table 4). Two-thirds of the powers estimated by 
the manufacturers were within $95 \%$ of the acceptance limit of flow cytometry.

Table 4: Comparison between anti-D concentration declared by the producer and concentration obtained by Flow Cytometry.

\begin{tabular}{|c|c|c|c|c|c|c|}
\hline Product & $\mathbf{n}$ & $\begin{array}{l}\text { Ave } r \text { a g e } \\
\mu \mathrm{g} / \mathrm{ml}\end{array}$ & Limit 95\% & $\mathrm{VC} \%$ & Declared Concentration $\mu \mathrm{g} / \mathrm{ml}$ & \% Recovery \\
\hline \multirow{3}{*}{$\mathrm{H}$} & 6 & 149.50 & $145-154$ & 2.6 & \multirow{3}{*}{150} & 99.7 \\
\hline & 6 & 150.25 & $146-155$ & 3.3 & & 100.2 \\
\hline & 6 & 142.64 & $140-144$ & 1.3 & & 95.1 \\
\hline \multirow{3}{*}{$\mathrm{P}$} & 6 & 236.25 & $218-254$ & 7.2 & \multirow{3}{*}{220} & 107.4 \\
\hline & 6 & 220.86 & $208-233$ & 5.7 & & 100.4 \\
\hline & 6 & 192.00 & $189-196$ & 2.1 & & 87.3 \\
\hline \multirow{3}{*}{ B } & 6 & 151.87 & $147-155$ & 1.9 & \multirow{3}{*}{164} & 92.6 \\
\hline & 6 & 147.1 & $145-151$ & 2.7 & & 89.9 \\
\hline & 6 & 183.64 & $176-189$ & 2.7 & & 111.9 \\
\hline
\end{tabular}

The differences between the declared and determined concentrations were estimated with the Wilcoxon test. A normal distribution is not assumed due to the limited amount of data.

30 samples of three commercial products (wellknown concentration) tested, only one presented a deviation in the cut-off of the concentrations determined by cytometry (87.3-111.9). The cytometry shows a good recovery in the samples tested, as shown in Table 4.

\section{Discussion}

The availability of a quantitation method for human plasma, Cohn's fractions and anti-D Gammaglobulin, have a relevant importance for the process control of the Anti-D IgG production.

In general, producers' Laboratories are employing sensitive EIA, RIA and Flow Cytometry techniques for the quantitation of Anti-D level in finished products but authors have not been reported its use in the control of productive processes [25].

In this work, we describe an in-house rapid and low-cost Flow Cytometry for direct anti-D quantitation in different samples (human plasma, Chon's fractions, Gammaglobulin).
Flow cytometry described was designed to be used as process control method in the anti-D gammaglobulin large-scale production. According to this, the threshold of the assay was adjusted to select the level of antibody content, which will be accepted, to produce an immunoglobulin with a potency of $250 \mu \mathrm{g} / \mathrm{vial}$ (1250 IU/vial), according to the regulatory requirements (European Pharmacopoeia).

To optimize the assay, factors that affect the uptake of antibodies by red blood cells were analyzed. Cell pack alterations in the wash and incubation temperature did not influence the assay. The sample diluent (PBS-1\% BSA, $\mathrm{pH} 7.2$ ) at $37^{\circ} \mathrm{C}$ increased 1000 -fold the rate of antibody association, including those with lower affinity, while the dissociation rate remained relatively constant [8].

Under the conditions used, the different samples behave similarly in terms of red blood cell binding. The FS shows that the concentration of globules used in the method does not present interference by auto agglutination as seen in Figure 7.

The cells with phenotype R1R1 present better performances for this test, and can be replaced if necessary by R1R2 globules, which present comparable values with the R1R1 (Table 1). 
Respect to the evaluation of Cytometry performance, the values of the coefficient of variation (1\%-7.5\%) revealed an adequate reproducibility and repeatability when a same sample was assayed on different days and showed a good correlation with standard dose curve (r: 0.9267). The specificity test is satisfactory considering that the negative controls showed insignificant levels of fluorescence. Recovery was in order to $95 \%$, confirmed by quantifying a defined amount of anti-D from different commercial gammaglobulins.

The plasma samples were within the parameters of the curve. Dilution 1/10 (102 ng/ml) showed better results and dilutions of $1 / 20$ guaranteed readings in the better linearity zone of the curve.

Fraction II not presented drawbacks, deviations were found in samples that exhibit turbidity and instability.

Working in the productive process condition ensures the stability of the fraction II. It was quantified in two dilutions $1 / 20-1 / 40$ and presented a good recovery $(98 \%)$ of the average concentrations $(38 \mu \mathrm{g} / \mathrm{ml})$. Inter-assay tests with different Fraction II showed an increase in antibody concentration attributable to the biological variability of the sample.

The determination in finished products, not present drawbacks or deviations in dilutions 1/16-1/32, obtaining $96.7 \%$ recovery and robust results in three different commercial products.

Apart from the need to have a method, special requirements of standardization and quality control must be met when Flow cytometry is established in a laboratory following the principles of a quality assurance system. The validation strategy was carefully selected, considering the matrices to be tested and the biological variability of the samples and red blood cells, because flow cytometry, as a bioassay, is more difficult standardized that a chemical-analytical assay. For validation our strategy was based on an international guide accepted by manufacturers and control laboratories [26]. For flow cytometry, it is used as a method to determine the specificity potency of a drug, all the validation characteristics (except the limit of detection and the limit of quantification) is elected.
The validation method meets requirements according to good manufacturing practices in the pharmaceutical industry $[27,28]$.

A validation methodology was followed to meet the special requirements of standardization of the good manufacturing practices in the pharmaceutical industry.

Biological variability, red blood cells and matrices were considered in a validation protocol according to international guidelines [26].

\section{Conclusions}

Flow cytometry is a sensitive and specific method that allows reproducible results and shows that the estimated concentrations are comparable with those reported by commercial gamma globulin manufacturers and that these values present a high degree of accuracy and precision. The test is completed in three hours and is easy to perform, allowing quantitative assessment of anti-D antibodies from plasma, fractions of the Cohn process and finished products. The flow cytometry method to quantify anti-D in different test matrices, described here has potential as an alternative to other employees and necessary criteria for a trial of this type is met, that is, it is simple, fast and reliable and both sensitive and accurate. Proof of your potential the use for anti-D quantification in control samples of the productive process has demonstrated its reproducibility, which is why the method is considered acceptable for anti-D quantification in process control.

\section{References}

1. Coombs RR, Mourant AE, Race RR. A new test for the detection of weak and incomplete Rh agglutinins. $\mathrm{Br} \mathrm{J}$ Exp Pathol 1945;26:255-266.

2. Rosenfield RE, Harber GV. Detection and measurement of homologous human hemagglutinins. Technicon Symposia. Automation in Analytical Chemistry 1966;503-506.

3. Moore BPL, Hughes-Jones NC. Automated assay of anti$\mathrm{D}$ concentration in plasmapheresis donors. Proceedings Technicon International Congress, Chicago. 1970.

4. Perrault R, Högman C. Automated red cell antibody analysis. A parallel study. I. Detection and quantitation. Vox Sang 1971;20:340-355.

5. Esposito VM, Paul EB, Seligmann EB. In vitro potency results from a collaborative study of $\mathrm{Rh},(\mathrm{D})$ immune globulin reference preparation. Vox Sang 1971;21:193-199. 
6. Gunson HH, Phillips PK, Stratton F. Observations on the reproducibility of the bromelised test cell anti-D assay using the auto-analyser. Vox Sang 1976;26:334-343.

7. Paul EB. Standardization of US reference Rho (D) immune globulin by quantitative automated hemagglutination. J Biol Standardization 1986;14:121-125.

8. Hughes-Jones NC, Gardner B, Telford R. Comparison Of Various Methods Of Dissociation Of Anti-D, Using 131iLabelled Antibody. Vox Sang 1964;8:531-536.

9. Hughes-Jones N, Dawes B, Gorick B, Melamed M, Pepper R, et al. Radio-immunoassay of the functional activity of anti-D (Rh) preparations using a human monoclonal 125I-labelled anti-D. Vox Sang 1987;53:175-180.

10. Bangham DR, Kirkwood TBL, Wybrow G, Hughes-Jones $\mathrm{NC}$, Gunson $\mathrm{HH}$. International collaborative study of assay of anti-D (anti-Rho) immunoglobulin. $\mathrm{Br} \mathrm{J}$ Haematol 1978;38:407-423.

11. Gunson HH, Bowell PJ, Kirkwood TBL. Collaborative study to recalibrate the International Reference Preparation of Anti-D Immunoglobulin. J Clin Pathol 1980;33:249-253.

12. Anonymous: Assay of human anti-D immunoglobulin 2-7-13; in European Pharmacopoeia, (edn) 4. Strasbourg. European Commission. 2002; .

13. Anonymous: 2.7.13 Assay of Human Anti-D Immunoglobulin: European Pharmacopoeia, (edn) 4. Strasboung. Directorate for the Quality of Medicines of the Council of Europe. [addendum 2003;4:3890-3892.

14. Anonymous: Human Anti-D Immunoglobulin (01/2004 0557): European Pharmacopoeia, (edn) 4. Strasboung. Directorate for the Quality of Medicines of the Council of Europe. 2003;

15. Austin EB, McIntosh Y, Hodson C, Lee D. Anti-D quantification by flow cytometry: An alternative to the AutoAnalyser? Transfus Med. 1995;5:203-208.

16. Thorpe SJ, Fox B, Sands D. A stable lyophilized reagent for use in a potential reference assay for quantitation of anti-D in immunoglobulin products. Biologicals 2002;30:315-321.

17. Thorpe SJ, Sands D, Rautmann G, Schäffner G. International collaborative study to evaluate methods for quantification of anti-D in immunoglobulin preparations. Vox Sang. 2002;83:42-50.
18. Thorpe SJ, Turner CE, Heath AC, Sands D. A competitive enzyme-linked immunoassay using erythrocytes fixed to microtitre plates for anti-D quantitation in immunoglobulin products. Vox Sang 2000;79:100-107.

19. Lambin P, Debbia M, Béolet M, Brossard Y, Le Pennec PY, et al. [Quantitative estimation by ELISA of IgG antiD (RH1) antibodies in immunoglobulin preparations and in the sera of immunized donors]. Transfus Clin Biol 2001;8:17-22.

20. Schäffner G, Kayser T, Tönjes A, Volkers P. Validation of flow cytometry to quantify the potency of anti-D immunoglobulin preparations. Vox Sang 2003;84:129-136

21. National Institute for Biological Standards and Control. 1st International Reference Preparation for Anti-D Immunoglobulin, Human. NIBSC Code: 68/419. Instructions for use, Version 2, 1 April 1998. South Mimms, UK, NIBSC, 1998.

22. Hildén JO, Backteman K, Nilsson J, Ernerudh J. Flowcytometric quantitation of anti-D antibodies. Vox Sang 1997;72:172-176.

23. Austin EB, McIntosh Y. Anti-D quantification by flow cytometry:a comparison of five methods. Transfusion 2000;40:77-83.

24. Fox B, Roberts G, Sharp G, Studholme L, Atkinson E, Rigsby $\mathrm{P}$, et al. International Collaborative Study to Calibrate Proposed 3rd WHO International Standard for Anti-D Immunoglobulin. WHO Expert Committee on Biological Standarizatrion. 2018.

25. Oviedo S, Romagnoli P, Collino C, Kassuha D, Vitali S. Desarrollo y Optimización de un Ensayo de Citometría de Flujo para Cuantificación de IgG-ANTI-D (Rho) en muestras del Proceso Productivo. (Reporte Corto). Revista Argentina de Hematología. 2005;117.

26. The International Conference on Harmonisation (1995): Note for guidance on validation of analytical procedures: Methodology (CPMP/ICH/281/95). European Agency for the Evaluation of Medicinal Products 1996.

27. Walter SD, Altman DG. Practical Statistics for Medical Research, (edn) 1. London, Chapman \& Hall. 1992;48:656.

28. WHO: 28th report. Expert Committee on Biological Standardization. WHO Technical Report Series 1977;610:29-30 